PRZEDSIĘBIORCZOŚĆ - EDUKACJA NR 1

KRAKÓw 2005

\author{
Maria Rachwal \\ Małopolskie Forum Przedsiębiorczości, Kraków \\ Tomasz Rachwal \\ Zakład Przedsiębiorczości i Gospodarki Przestrzennej \\ Instytut Geografii \\ Akademia Pedagogiczna, Kraków
}

\title{
Rola kształcenia umiejętności obsługi klienta na lekcjach podstaw przedsiębiorczości
}

Procesy globalizacji i integracji Polski z Unią Europejską na płaszczyźnie gospodarczej, powodują konieczność sprostania przez polskie przedsiębiorstwa rosnącej presji konkurencyjnej przedsiębiorstw zagranicznych. Na polski rynek wchodzą nowe firmy, a te które dotychczas funkcjonowały na polskim rynku będą kontynuować ekspansję. Istnieje obawa, że polskie przedsiębiorstwa - szczególnie z sektora małych i średnich przedsiębiorstw - nie będą w stanie sprostać konkurencji ze strony zachodnioeuropejskich przedsiębiorstw posiadających duże zasoby kapitałowe, które przeznaczone mogą być na stosowanie cen dumpingowych, intensywne kampanie reklamowe czy, co szczególnie istotne w przypadku przedsiębiorstw handlowych, na doskonałą lokalizację punktów sprzedaży i atrakcyjne promocje. Powszechnie przyjmuje się, że o zdolności konkurencyjnej przedsiębiorstwa decyduje przede wszystkim jakość i cena oferowanych produktów bądź usług. Należy jednak podkreślić - za L. J. Jasińskim (2000) - że nie są to jedyne ważne własności decydujące o konkurencyjności przedsiębiorstwa. Równie istotne są elementy składające się na konkurencyjność pozacenową, do których zalicza się różne rozwiązania marketingowe. Jednym z takich niedocenianych i zaniedbywanych przez polskich przedsiębiorców narzędzi marketingowych jest obsługa klienta. Należy podkreślić, że we współczesnej gospodarce podstawowym warunkiem zaistnienia na rynku, zdobywania i utrzymywania klientów stało się zapewnienie znakomitej obsługi.

W świetle przedstawionych przesłanek przyjęto, że problematyka obsługi jest kluczowa $\mathrm{w}$ nauczaniu podstaw przedsiębiorczości, ponieważ zgodnie z podstawą programową $\mathrm{w}$ toku nauczania tego przedmiotu uczeń ma być przygotowany do założenia i prowadzenia własnej firmy (Podstawa programowa...2002). Ponadto należy założyć, że każdy uczeń - po zakończeniu nauki lub jeszcze w jej trakcie - będzie pracował w jakimś przedsiębiorstwie, a więc od jego umiejętności obsługi klienta będzie zależała w pewnej części pozycja konkurencyjna przedsiębiorstwa, w którym pracuje. Problematyka obsługi klienta została ujęta $\mathrm{w}$ koncepcji nauczania tego przedmiotu autorstwa Z. Makieły i T. Rachwała (Makieła, Rachwał 2002, 2003, 2005a, 2005b; Rachwał 2004). Przedmiotem artykułu są więc treści kształcenia z zakresu umiejętności obsługi klienta, które powinny być poruszone w toku nauczania „przedsiębiorczości”. Należy nadmienić, że treści te w zakresie znacznie poszerzonym powinny być realizowane $\mathrm{w}$ ramach kształcenia profilowego $\mathrm{w}$ liceum profilowanym i technikum w bloku tematycznym „obsługa klienta”.

Pierwszą i podstawową powinnością nauczyciela „przedsiębiorczości” realizującego treści z zakresu obsługi klienta, jest uświadomienie uczniów o roli tej obsługi w osiąganiu 
przewagi konkurencyjnej przedsiębiorstwa. Oczywiste jest, że każda firma dąży do uzyskania przewagi nad konkurencją. Jednak często - w sytuacji gdy firma poprzestaje na obniżaniu ceny lub wprowadzaniu nowego produktu - jest to przewaga chwilowa. Próba prostego osiągania przewagi konkurencyjnej przez wprowadzanie nowego produktu jest krótkotrwała, gdyż produkt ten - szczególnie w segmencie tzw. dóbr szybkozbywalnych (FMCG) - może być łatwo i szybko kopiowany przez konkurencję. Podobnie jest z polityką cen, która nie może polegać na ich obniżaniu w nieskończoność. Niskie ceny oznaczają przecież niskie marże i w konsekwencji bardzo często niskie zyski. Cześć firm popełnia również błąd, polegający na działaniu według zasady „dziurawego wiadra” czyli zasady, że zawsze będzie wystarczająco dużo nowych klientów, którzy zastąpią klientów odchodzących. Oczywiście takie firmy - jeżeli nie zajmują pozycji monopolistycznej lub prawie monopolistycznej - są skazane na eliminację z rynku.

Powstaje więc pytanie - jeżeli przedsiębiorstwa sprzedają podobne produkty w zbliżonych cenach - to co decyduje o sukcesie firmy? Najtrafniej wyraził to „guru współczesnego zarządzania" Peter F. Drucker "Celem każdej firmy jest kreowanie i utrzymywanie klientów" (Drucker, 1998). Uczniowie muszą być świadomi, że właściwa kombinacja ceny i jakości produktu nie wystarczy na współczesnym konkurencyjnym rynku, by zdobyć lojalnego klienta. Pozwala ona jedynie na dopuszczenie do gry o niego. Sztuką jest więc nie tylko zdobycie, ale utrzymanie lojalnych klientów.

Należy zdawać sobie sprawę, że klienci są najważniejszym kapitałem firmy. Wystarczy przytoczyć - za W. W. Larsonem (2003) - kilka danych:

- $\quad 90 \%$ klientów, którzy byli niezadowoleni z poziomu obsługi klienta, nie wraca już do nieprzyjaznej firmy.

- Niezadowolony klient opowie o nieprzyjemnym kontakcie z firmą średnio dziewięciu innym osobom. Możemy założyć, że dzięki internetowym forum, będzie ich znacznie więcej. W łańcuszku osób, do których dotrze negatywna informacja, mogą być osoby opiniotwórcze (dziennikarze, wykładowcy itp.).

- $68 \%$ klientów, którzy byli potraktowani obojętnie, nie będzie już korzystać z usług firmy.

- W oczach klienta potrzeba aż 12 dobrych przypadków obsługi, by zrównoważyć jeden przypadek negatywny.

Według badań marketingowych pozyskanie nowego klienta może być ponad 5krotnie droższe niż utrzymanie stałego klienta (Kotler 1999). Lojalny klient kupuje coraz częściej, płacąc coraz więcej a ponadto poleca firmę swoim znajomym. Taki klient jest dla przedsiębiorstwa tańszy w obsłudze i bardziej zyskowny, ponieważ firma zna jego potrzeby i najbardziej skuteczne sposoby zawierania transakcji. A stały klient to przede wszystkim klient zadowolony nie tylko $\mathrm{z}$ jakości produktu, ale także $\mathrm{z}$ poziomu obsługi. Istotna w procesie obsługi klienta jest więc znajomość koncepcji „wartości życiowej klienta” (life time value of customer), czyli wartości pieniędzy, jaką klient wyda w danej firmie przez całe swoje życie, jeżeli będzie z nią związany.

Rola obsługi klienta w osiąganiu przewagi konkurencyjnej przedsiębiorstwa wynika także z faktu, że dobra obsługa klienta jest trudna do skopiowania. Obsługa klienta to nie jest tylko uśmiech pracownika tzw. „pierwszej linii”, lecz cała struktura organizacyjna i kultura firmy. Ponadto rola dobrej obsługi klienta staje się coraz ważniejsza, bo we współczesnych czasach, funkcja sprzedażowa tej obsługi zmienia się w funkcję doradczą. Szczególnie jest to ważne w sektorze usług, gdzie sprzedawane są towary niematerialne, które stają się materialne dopiero $\mathrm{w}$ trakcie konsumpcji (np. usługa turystyczna, gastronomiczna). Przed ich zakupem klient kształtuje swoją opinię głównie w oparciu o kontakt z pracownikiem firmy, oceniając czy jest miły, rzetelny, punktualny, profesjonalny itp.

Uświadomienie roli obsługi klienta jest wstępem do wyjaśnienia uczniom na czym polega doskonała obsługa klienta. Na wstępie powstaje więc pytanie, jak można określić dobrą obsługę klienta? Ogólnie można przyjąć, że jest to sposób postępowania, który stawia 
klienta na pierwszym miejscu w każdym aspekcie działalności przedsiębiorstwa. Zagorzali zwolennicy obsługi klienta przytoczyliby jeszcze inną definicję: Jest to „sposób życia, który zakłada stawianie klienta na pierwszym miejscu w każdym aspekcie działalności. Jest to sposób prowadzenia interesów, które ma swe źródło w szczerej trosce o klienta. Charakteryzuje się on obsesyjnym dążeniem do zaspokajania potrzeb klienta podczas każdego z nim kontaktu. Obsesja ta dotyczy każdego pracownika firmy, poczynając od prezesa zarządu a na sprzątaczce kończąc".

Skuteczne wprowadzenie obsługi klienta na jak najwyższym poziomie wymaga zmiany kultury organizacyjnej przedsiębiorstwa, w ramach której każdy aspekt działalności jest podporządkowany klientowi. W tworzeniu kultury firmy opartej na obsłudze klienta musi być zaangażowany każdy jej pracownik. Sukces mogą odnieść jedynie te przedsiębiorstwa, w których każdy pracownik zna ostateczny cel swojej pracy, czyli zadowolenie klienta. Wprowadzanie kultury organizacyjnej opartej na podporządkowaniu wszystkich działań dobru klienta powinno się rozpocząć od wprowadzenia tej zasady wewnątrz przedsiębiorstwa. Pracownicy przedsiębiorstwa powinni nawzajem traktować się jak klienci - tzw. klienci wewnętrzni. Wyjaśniając uczniowi, kto jest tym „tajemniczym” klientem wewnętrznym, nauczyciel powinien mu uświadomić, że to każdy bez wyjątku pracownik firmy dla siebie nawzajem. Sekretarka dla szefa, księgowa dla kadrowej, sprzątaczka dla prezesa. Przykładowo - jeżeli wypłaty nie będą przelane terminowo na konto, istotne informacje nie będą docierały do zainteresowanych, pisma będą nieprofesjonalnie zredagowane itp. - to w perspektywie odbije się to również na zewnętrznym wizerunku przedsiębiorstwa. Jakość usług zewnętrznych nie może bowiem przewyższać jakości usług wewnętrznych (Szczepanik 2000).

Celem każdego przedsiębiorstwa jest jednak troska o klienta zewnętrznego, dlatego jego obsłudze powinno się poświęcić najwięcej miejsca $\mathrm{w}$ toku nauczania tej problematyki na lekcjach ,przedsiębiorczości”. Przede wszystkim uczniowie powinni zrozumieć, że podstawowym błędem jest postrzeganie transakcji z klientem zewnętrznym jako jednorazowej i niepowtarzalnej. Obsługa klienta polega przede wszystkim na budowaniu długotrwałych, partnerskich relacji. Prawdziwej lojalności nie da się kupić, charakteryzuje się bowiem wysokim poziomem wzajemnego szacunku, który trzeba sobie zaskarbić poprzez zaspokajanie potrzeb i spełnianie wyrażonych przez klienta oczekiwań.

Do elementów dobrej obsługi klienta należy zaliczyć przede wszystkim przyjęcie przez każdego pracownika postawy „klient jest najważniejszy”, co powinno być zawarte w misji i wizji firmy, a także w procedurach postępowania. Czasami wizja traktowania klienta jest bardzo skonkretyzowana, jak w przypadku McDonalda:

1. Klient jest najważniejszą osobą w naszej branży.

2. Klient nie potrzebuje nas - to my potrzebujemy klienta.

3. Klient nie przeszkadza nam w pracy, lecz nadaje jej sens.

4. Klient robi nam zaszczyt, gdy przychodzi. Nasza służba klientowi nie jest dla niego przysługą.

5. Klient jest częścią naszej branży, a nie osobą z zewnątrz.

6. Klient to nie kawałek statystyki, ale człowiek z krwi i kości - żywa osoba, która posiada uczucia takie jak my.

7. Z klientem nie należy się spierać.

8. Klient zasługuje na najgrzeczniejsze i najbardziej sumienne traktowanie, jakie możemy zapewnić.

9. Klient przychodzi do nas ze swoimi żądaniami. Do nas należy ich spełnianie.

10. Klient ma prawo wymagać, by pracownik prezentował się czysto i schludnie.

Zaangażowanie Mc Donalda w obsługę klienta uczyniło firmę jednym z modeli sukcesu XX w. Dlaczego w przeciwnym razie tyle milionów ludzi kupowałoby zwykłą bułkę z kawałkiem mięsa lub ryby? 
Do istotnych elementów obsługi klienta należy ponadto zaliczyć ${ }^{1}$ :

- Postępowanie zgodne ze standardami, które obowiązują wszystkich pracowników: np.: odbieranie telefonu po trzecim sygnale, umiejętność prowadzenia rozmów telefonicznych i obowiązującej podczas nich etykiety, przedstawianie się, kontakt wzrokowy; dotrzymywanie obietnic.

- Nastawienie pracowników głównie na pomoc klientowi, a nie inne zadania - klient bowiem wymaga natychmiastowej uwagi.

- Zorientowanie na rozwiązywanie problemów, a nie przyjmowanie postawy, że „problem zniknie sam" (niestety najczęściej znika klient i to na zawsze).

- Szacunek - traktowanie swojego klienta tak, jakbyś sam chciał być traktowany. Szacunek jest podstawą budowania zadowolenia i lojalności klienta.

- Fachowość - posiadanie dostatecznej wiedzy, by odpowiedzieć na pytania klienta i odpowiednio mu doradzić.

- Zdobywanie i analizowanie informacji zwrotnej od klienta. Większość firm stara się unikać skarg, traktując to jako porażkę, nie uświadamiając sobie, że każda skarga umożliwia nam poprawę obecnej sytuacji i stworzenie doskonałej obsługi klienta.

- Elastyczny sposób zaspokajania potrzeb klientów. Jednolite podejście do obsługi klienta jest nieodpowiednie, gdyż każdy klient jest inny i ma inne potrzeby. Ważne są tu również szerokie uprawnienia pracowników, którzy mogą szybko zareagować na skargę klienta bez zbędnych procedur.

- Szybkie i sprawne rozpatrywanie reklamacji, tak aby klient był maksymalnie usatysfakcjonowany. Wg badań marketingowych około 52\% (w przypadku poważnych reklamacji) i 95\% (drobne reklamacje) klientów, których reklamacja została pozytywnie rozpatrzona powtórnie wraca do firmy i często poleca ją znajomym (Kotler 1999). Szczególną uwagę należy zwrócić na konieczność indywidualnego rozpatrywania reklamacji. Powstanie szablonowej odpowiedzi sprawia wrażenie u klienta, że nie traktowany jest poważnie i że takie reklamacje zdarzają się bardzo często.

- Podejmowanie decyzji uwzględniające przede wszystkim dobro klienta, a nie procedury czy wewnętrzne zarządzenia.

- Biegłość w kontaktach międzyludzkich czyli grzeczność, uprzejmość, uczciwość, umiejętność aktywnego słuchania i tym samym zdobywania informacji, jakie są potrzeby klienta i w jaki sposób można je zaspokoić.

- Relacje oparte na partnerstwie, czyli współpracy. Współcześnie usługodawca stara się raczej zaspokoić prawdziwe potrzeby klienta i woli nie sprzedać usługi lub produktu, gdy nie odpowiada w pełni oczekiwaniom klienta. Tak buduje klimat zaufania.

W celu utrzymania wysokiego poziomu obsługi niezbędny jest rozbudowany system szkoleń pracowników, jednorazowe szkolenie w tym zakresie nie przynosi bowiem pożądanych efektów. Szkolenia muszą być systematycznie powtarzane i utrwalane w miejscu pracy w systemie „coaching”. Osoby zajmujące się obsługą klienta powinny być szkolone przede wszystkim z zakresu tzw. „miękkich” umiejętności, takich jak umiejętność słuchania, rozwiązywania konfliktów, opanowania i empatii. Zanim firma ustali program szkoleń pracowników powinna zidentyfikować prawdziwe i najważniejsze potrzeby jej klientów, np. elastyczność, szybkość obsługi, sprostanie indywidualnym potrzebom czy kompleksowość obsługi. Szkolenia powinny być poparte przykładem wzorowego stosowania zasad obsługi klienta przez kierownictwo. W razie braku takich pozytywnych przykładów nakłady poniesione na szkolenia mogą być stracone. Przedsiębiorstwa, które chcą wykorzystać obsługę klienta jako ważne narzędzie marketingowe, powinny tworzyć specjalne podręczniki, w których ujęte są stosowane standardy obsługi oraz listy zachowań związanych z tworzeniem

\footnotetext{
1 Por. film, symulacje i ćwiczenia interaktywne nt. profesjonalnej obsługi klienta przedstawione w multimedialnym CD-ROMie podstaw przedsiębiorczości (Śrutowska, Rachwał 2005).
} 
pozytywnego wizerunku firmy: począwszy od sposobu odbierania telefonu, przywitania, prowadzenia rozmów, przyjmowania reklamacji a skończywszy na pożegnaniu klienta. Procedury powinny być spisane w postaci jasnych reguł, przy zachowaniu możliwości elastycznego ich zastosowania.

Kolejnym nieodzownym elementem skutecznego wprowadzenia wysokiego poziomu obsługi klienta jest odpowiednia motywacja pracowników do wykonywania swoich zadań. Zadowolony pracownik przelewa bowiem swój entuzjazm na kontakt $\mathrm{z}$ klientem. Pomimo faktu, że wiele przedsiębiorstw nie stać na wysokie wynagrodzenia dla pracowników tzw. „pierwszej linii”, nie należy zapominać o innych, pozafinansowych środkach motywacji, które często są bardzo skuteczne. Pomocne może być stosowanie czasowo-premiowego lub czasowo-prowizyjnego systemu płac, który uświadamia pracowników, że ich wynagrodzenia zależą bezpośrednio od stopnia zadowolenia klientów.

Systemem pomocnym w obsłudze klienta jest CRM (Customer Relationship Managment), który umożliwia zbieranie danych o kliencie, zrozumienie jego potrzeb i ułatwianie podejmowania przez niego decyzji. Pakiet analityczny systemu CRM umożliwia analizę przewidywań w stosunku do poszczególnych grup klientów, modelowanie zachowań klienta oraz pozycjonowanie wartości klienta. CRM pozwala określić skłonność klientów do rezygnacji ze świadczeń oraz wyznaczyć wartość klienta w czasie. Za jego pomocą badany jest również poziom satysfakcji i lojalności klientów (Konkol 2004). Wprowadzenie takiego systemu jest jednak bardzo kosztowne, przy czym nie jest to koszt jednorazowy, dosyć wysokie mogą być także stałe koszty obsługi. Należy pamiętać, że CRM to nie tylko system informatyczny, lecz także filozofia, którą mogą stosować wszyscy. Jest to bowiem taki sposób prowadzenia firmy, w której klient, jego potrzeby i oczekiwania są w centrum zainteresowania (Zachara 2000).

W świetle przedstawionych rozważań należy stwierdzić, że w sytuacji silnej konkurencji w otoczeniu, w celu utrzymania dotychczasowych i zdobycia nowych klientów konieczne jest oferowanie przez przedsiębiorstwa obsługi klienta na wysokim poziomie. Małe i średnie firmy mogą stosunkowo niskim nakładem kapitału doskonalić to narzędzie marketingowe, często zaniedbywane $\mathrm{w}$ ponoszeniu pozycji konkurencyjnej. Zdobycie lojalnych klientów zapewnia stały i znaczący dochód dla przedsiębiorstwa, zgodnie z marketingową zasadą, że $20 \%$ stałych klientów dostarcza aż $80 \%$ przychodów. Budowanie doskonałych relacji z klientem może $w$ istotnym stopniu przyczynić się do podniesienia konkurencyjności przedsiębiorstw oraz konkurencyjności samych uczniów szkół ponadgimnazjalnych, którym ta umiejętność będzie bardzo przydatna w życiu zawodowym. Dlatego też rola kształcenia tych umiejętności jest nieoceniona w nauczaniu podstaw przedsiębiorczości.

\section{LITERATURA}

Drucker P. F., 1998, Praktyka zarządzania, wyd II, Wyd. Nowoczesność, Akademia Ekonomiczna w Krakowie, Warszawa-Kraków.

Jasiński L. J., 2000, Konkurencyjność gospodarek krajów Unii Europejskiej a ewolucja prowadzonych przez nia polityk [w:] Konkurencyjność gospodarki Polski w dobie integracji z Unią Europejską i globalizacji, T. I., pod red. J. Bossaka i W. Bieńkowskiego, Instytut Gospodarki Światowej SGH, Warszawa.

Konkol S., 2004, Obstuga na bitach, „Businessman Magazine", Nr 156,03/2004.

Kotler P., 1999, Marketing. Analiza, planowanie, wdrażanie i kontrola, Wydawnictwo Felberg SJA, Warszawa.

Larson W. W., 2003, Obstuga klienta, Wydawnictwo K. E. Liber s. c., Warszawa.

Makieła Z., Rachwał T., 2002, Podstawy przedsiębiorczości. Program nauczania dla liceum ogólnokształcącego, liceum profilowanego i technikum, Wydawnictwo Nowa Era. Warszawa. 
Makieła Z., Rachwał T., 2003, Podstawy przedsiębiorczości. Poradnik metodyczny dla nauczycieli liceum ogólnokształcacego, liceum profilowanego i technikum. (wydanie drugie zm.), Wydawnictwo Nowa Era. Warszawa.

Makieła Z., Rachwał T., 2005a, Podstawy przedsiębiorczości. Podręcznik dla liceum ogólnoksztatcacego, liceum profilowanego i technikum (wydanie trzecie zm.), Wydawnictwo Nowa Era. Warszawa.

Makieła Z., Rachwał T., 2005b, Podstawy przedsiębiorczości. Zeszyt ćwiczeń dla liceum ogólnokształcacego, liceum profilowanego i technikum. (wydanie trzecie zm.), Wydawnictwo Nowa Era. Warszawa.

Podstawa programowa kształcenia ogólnego (dla liceum ogólnokształcacego, liceum profilowanego i technikum), Rozporządzenie Ministra Edukacji Narodowej i Sportu z dn. 26 lutego 2002 r., Warszawa.

Rachwał T., 2004, Podstawy przedsiębiorczości. Słownik dla liceum ogólnokształcacego, liceum profilowanego i technikum. Wydawnictwo Nowa Era. Warszawa.

Szczepanik R., 2000, Bądź kolega, dopieść klienta, „Businessman Magazine", Nr 115, $10 / 2000$.

Śrutowska D., Rachwał T. (red.), 2005, Podstawy przedsiębiorczości. Multimedialny CD-ROM dla liceum ogólnoksztatcacego, liceum profilowanego i technikum. Wydawnictwo Nowa Era, Young Digital Poland, Warszawa-Gdańsk.

Zachara M., 2000, Klient wciąż nie nasz pan, „Businessman Magazine", Nr 115, 10/2000. 